\title{
THE HEALING HAND: THE ROLE OF WOMEN IN ANCIENT MEDICINE
}

\begin{abstract}
In contrast with the struggle of $19^{\text {th }}$ and $20^{\text {th }}$ century women all over the world to be admitted to medical schools, women in ancient Greece and Rome were apparently increasingly at liberty to practise medicine from the $4^{\text {th }}$ century $\mathrm{BC}$ onwards. The available evidence offers conclusive proof of this more tolerant attitude. The sources are few in number, but fragmentary information can be gleaned from medical writers, passing remarks in Greek and Latin authors, and funerary inscriptions. These sources emphasise the professions of midwife and female doctor. Although there is some overlap between their duties, we find that in Greece a distinction was drawn between maia and iatrike $e$ as early as the $4^{\text {th }}$ century $\mathrm{BC}$, while in Rome the two professions of obstetrix and medica or iatrina were well established by the $1^{\text {st }}$ century BC. The training, personal characteristics, qualifications, duties, status and remuneration of practitioners of the two professions will be considered in this study. The funerary inscriptions of female doctors reveal that they were honoured in the same way as men for exceptional services; medical works were also dedicated to them as colleagues, and those of them who wrote texts of their own were quoted with respect. Thus, although there were never very many female doctors, the classical world does not seem to have placed insurmountable obstacles in the way of women who wished to practise medicine.
\end{abstract}

\section{INTRODUCTION}

One of the most famous group statues of the $17^{\text {th }}$ century Italian sculptor Bernini is that of Aeneas, fleeing from the burning city of Troy with his elderly father on his shoulders and his young son alongside him at the end of the 10-year war between the Greeks and the Trojans. Admiring it, one naturally wonders where his wife, Creusa, is, and why she is not depicted as part of the family group. Virgil has his hero provide the answer:

I do not know; I have not seen her again, and when she became separated from me, I did not look back or think of her again until we came to the hillock and the ancient sanctuary of Ceres (Aeneid II. 739-44).

Particularly in the early years of the feminist movement, which influenced studies on classical antiquity as well as other disciplines, Aeneas's extremely unfeeling comment was castigated as one of the many "proofs" of the inferior position of women in ancient Greece and 
Rome. ${ }^{1}$ The extremity of this initial reaction against the negative perception of women eventually made way for more rational approaches in which women were considered as autogenous beings, rather than evaluated on the basis of their inability to think and act like men. ${ }^{2}$ An approach which has gained many adherents in recent years, in Classics as elsewhere, emphasises gender not as a biological category distinguishing between men and women, but as the set of social and cultural differences which communities construct in order to distinguish between masculinity and femininity and which may be seen to be reflected in the literature, art and culture (inter alia) of any era. ${ }^{3}$ Women in the ancient world have also been considered from many other perspectives. ${ }^{4}$ Over the past few years the emphasis has shifted to more general descriptions of women in their sociological context, yet when generalisations have been made, the conclusion still seems to be drawn that women were suppressed and lived a life of isolation and deprivation. However, if one moves from this wide-angled view to a telephoto focus, the image changes, and it emerges that there were indeed women in classical antiquity who contributed to cultural life, such as poets and painters, ${ }^{5}$ and even some who pursued respected careers outside the home, for example in the field of medicine. This study will focus on the latter group, in order to provide a detailed examination of the role played by women in ancient medicine. The period under discussion extends from the height of Greek civilisation (the $5^{\text {th }}$ century BC) to the Roman Empire of the $4^{\text {th }}$ century AD. ${ }^{6}$

1 See the discussion of the various theories in this regard in Claassen (1998:38-40).

2 See the collection of essays by Skinner (1987) with the descriptive title Rescuing Creusa: new methodological approaches to women in antiquity.

3 See Beard (1993:29-35) and Claassen (1998:40-41) for further literature on the subject.

4 One must, however, guard against simplistic references to "women in classical times", since the position of women changed significantly over the years and the centuries and there was also an enormous difference between women in the higher and lower classes. See in this respect especially Beard (1993:29-35).

5 See for example the list of female painters in Pliny, Historia Naturalis xxxv. 40.

6 Much research has already been done on the role of women in medicine in the Middle Ages; see Green (1989); Benedek (1975); Greilsammer (1991). On the uphill battle of women in later ages to gain access to academic institutions, see Bonner, To the ends of the earth: women's search for education in Medicine (1992). 


\section{DEFINITION OF TERMS}

Women served in various medical capacities in Graeco-Roman antiquity. Their most important role was that of the midwife, assisting at births - surely one of the oldest professions in human history. At a more specialised level there were female doctors, although never very many. The role of nurse was unknown to the Greeks and Romans, being a profession which developed relatively late from the role of female deacon in the early Christian church. ${ }^{7}$ The ancient medical sources such as Hippocrates, Herophilus, Soranus or Galen make no mention of trained nursing personnel assisting doctors on a regular basis. ${ }^{8}$ When necessary, doctors appear to have made use of slaves, or the members of a patient's family, as assistants. In the domestic context the materfamilias would have provided any nursing or related services required by her family or by the slaves of the household. ${ }^{?}$

7 Valuable information about health services in Bible times is provided by Wassermann (1997). Various women in the early Christian period devoted themselves to charity and the care of the sick, the most famous being Fabiola, a highly-placed Roman widow and friend of the Church Father Jerome. In AD 390 she had a hospice erected for the sick in Rome - the first hospital in the modern sense of the word in Western history - and nursed there with great dedication, as we read in Jerome's praise of her (Letter LXXVII.6, Ad Oceanum de morte Fabiolae).

8 No provision was made for long-term treatment - the idea of a hospital was unknown to the Greeks and Romans. There were institutions caring for sick soldiers on the borders of the Roman Empire (the valetudinaria) and for sick slaves on large estates, but no organised institutions for civilian patients. Only in the $3^{\text {rd }}$ century $\mathrm{AD}$ was provision made for these, under the influence of the inns or xenodochia established by the Christians in the Greek Orient to offer overnight hospitality to pilgrims and to messengers travelling between bishoprics. The temples of Asclepius to which people flocked for dream-healing and incubation sleep could possibly be seen as a precedent for modern hospitals, but came closer to hydropathic establishments such as Lourdes today. For more information in this regard, see Cilliers (1993:10-23) [pp. 62-78 in this volume].

9 There are many references in literature and history to women who knew the properties of herbs and were active in the production of medicines (for good or ill), e.g. Helen, who put a magic herb into the wine which she gave her guests, to make them calm and forgetful of their suffering at Troy (Homer, Od. IV.227230) and Medea, the wife of Jason, who made use of magic potions on many occasions during her eventful life (cf. Rosher 1965:Vol. II.2, 2482-2515). As 
This study will focus specifically on the role of midwives and female doctors. It is not possible to delineate the division between the two professions with precision as their tasks overlapped considerably. ${ }^{10}$ One must also take care not to impose modern medical categories and labels on the ancient world, since it had no system for the registration of professions in terms of specific qualifications. ${ }^{11}$ Anyone could practise as a doctor - one's reputation served as one's "certification".

From references in the literature, the two professions appear to have been identified at a very early stage. For instance, we find in Plato's dialogue Theaetetus (149 a1-c2) that Socrates compared his attempts to train the youth to give clear articulation and expression to their thoughts on the important aspects of life with the task of a midwife (maia). He also expressed surprise that his companion did not know that he is the son of a midwife, Phainarete. From this we may deduce that the profession of midwife was well established and respected in the society of Plato's day. There is less certainty about the profession of female doctor. Kudlien, for instance, emphatically rejects the notion that female doctors could practise in ancient Greece. ${ }^{12}$ But Plato's Republic (Bk. V.454 d2ff.) provides confirmation of their existence. In his conjectures about the ideal state, Plato imagines a society in which the most advanced intellects - whether male or female — may become

far as historical figures are concerned, the Roman physician and author Scribonius Largus referred in his De Compositione Medicamentorum Liber to several prominent women of his day (the $1^{\text {st }}$ century AD) who were known for their home-made remedies, e.g. Livia, the wife of Emperor Augustus; Octavia, the sister of Augustus and wife of Mark Antony, and Messalina, the wife of Emperor Claudius.

10 See Jackson (1988:191 n. 12) and Nickel (1979:515-518).

11 King (1986:59). Cf. also Nutton (1985:33 n. 32):

"Healer" would carry different meanings and would easily allow a broad range of styles and statuses among those it denoted.

Even the word iatros which is usually translated as "doctor" or "physician", means literally only "healer". Cf. also in this regard Wassermann (1997:163).

12 Considering the socio-cultural aspects of the selection of future Greek physicians ... it must be emphasised that in Greece about 400 BC it was impossible for two groups of persons to become physicians: women and slaves. Women would be concerned only with midwifery ... (Kudlien 1970:8). 
physicians or even rulers. ${ }^{13}$ He thus uses an example of an existing and accepted practice to support his actual argument for women's competence to act as rulers in his ideal state. The passing nature of the reference proves that the female doctors (iatrikê) were not uncommon in his day. ${ }^{14}$

Plato's "enlightened" view is confirmed by an inscription composed for Phanostrate in the $4^{\text {th }}$ century BC (quoted below). She was both a midwife (maia) and a doctor (iatros) — in other words, her medical services comprised much more than assistance at confinements. However, although this inscription provides incontrovertible epigraphic proof of the existence of a female doctor in the $4^{\text {th }}$ century BC, it must be placed in perspective and may not be taken as proof that large numbers of women had started to practise as doctors at this stage.

During the Hellenistic period (the $4^{\text {th }}$ and $3^{\text {rd }}$ centuries $\mathrm{BC}$ ), the Greek term iatrinê appears as a female form of iatros, possibly due to the existence of increasing numbers of female doctors. The term iatromaia exists somewhere between these two terms, possibly describing a midwife who has also had more specialised training. By the $1^{\text {st }}$ century BC, a female doctor in the Greek Orient could be addressed as a colleague by her male peers, as is indicated by a letter from the empiricist Heraclides of Taras to the female doctor Antiochis (Kudlien 1970:34 n.70).

13 It is ironic that Plato, who was a sworn bachelor and a great admirer of Socrates's lack of susceptibility to the sexual attractions of women (as demonstrated, inter alia, in his Symposium), and who, like most Athenian men of his time, was bisexual (cf. Halperin 1990:257), was one of the greatest campaigners in history for equal rights for women. The locus classicus of Plato's "feminism" is Bk. V of his Republic, in which he proposes the same education for girls as for boys, as well as liberating women belonging to the highest castes, the Rulers and the Guards, from domestic duties and child-rearing in order to devote their attention to affairs of state. It was Plato's view that women did not differ from men except in their ability to bear children, since the human soul was genderless (Rep. V.454 d2).

14 Pomeroy (1978:500) notes:

[Plato's] case rests on the actual existence of female physicians in the Athens of his day, when the profession of physician was the only occupation available to women that was respected... 
In Rome, the usual name for a midwife was obstetrix, while a doctor was called medicus and a female doctor medica ${ }^{15}$ (or sometimes iatrina). In the course of time, the medicaeliatrinae were increasingly viewed as equal partners of their male colleagues in the Roman Occident, in terms of both their training and their professional rights. This is demonstrated, inter alia, by a law passed by the Emperor Justinian in the year $\mathrm{AD} 530$, which refers to male and female doctors on an equal footing. ${ }^{16}$ Even at this stage, although there are many references to medicae in inscriptions ${ }^{17}$ — this being one of the few male professions accessible to women - there were still relatively few female doctors, and they were rather the exception than the rule. ${ }^{18}$

\section{SOURCES}

There are few sources offering evidence for this study. ${ }^{19}$ No biographies of these women, or tracts on their training or daily activities, exist. Information about women in the medical profession or offering a medical perspective on women must be gleaned from such literature as the works of the medical writers Soranus, Galen and others (see below), as

15 The existence of the profession of independent female doctor in Rome is indisputable. Cf. inter alia the passing reference in Martial 11.71.7 to a medica (whose role in the incident mentioned is not that of a midwife), which indicates that the existence of women practising this profession was an accepted fact.

16 sin autem sit ... medicus sive masculus sive femina. Reference taken from Kudlien (1970:35 n. 71).

17 Cf. the Corpus Inscriptionum Latinarum II.497; V.3461; VI.6851, 7581, 8711, 8926, 9614-7, 9619; VIII.24679; IX.5861; XIII.2019, 3343, 4334. References taken from Jackson (1988:191 n. 4).

18 Kudlien (1970:35 n. 71) notes in this regard:

It may be remarked that in some of the testimonies the women doctors are praised not only with admiration but also with amazement as equal to male colleagues.

Cf. also the funerary inscription of Pantheia, below.

19 Although more has been written in and about ancient medicine than in any other literary genre in Greek or Latin, proportionally little is extant. One inscription, for instance, tells of a doctor who wrote 256 books (Inscriptiones Graecae XIV.1759) - of which not a single fragment has survived (reference taken from Drabkin [1944:350]). 
well as from passing references in other Greek and Latin authors, supplemented by epigraphic material such as inscriptions on graves and on other commemorative artefacts (about 40 of which are extant, though not all were accessible), as well as the supporting evidence of the remains of other artefacts such as vases and fresco's as well as archaeological excavations. The mere fact that so little information is available may be significant, insofar as it may indicate that the presence of women in the medical profession was not an exceptional phenomenon demanding special mention.

\subsection{The literature}

As mentioned above, we find in the Theaetetus of Plato (c. 429-347 BC) a passing reference to the profession of midwifery, and in his Republic one to female doctors, with the impression being created in both cases that he viewed their existence as entirely natural.

Herophilus (320-260 BC), a Greek physician practising in Alexandria in Egypt, and one of the very few doctors to have dissected human cadavers before the $19^{\text {th }}$ century, made an important contribution to knowledge of the female anatomy. His work, the Maieutikon (of which only fragments are extant), is the earliest known work on obstetrics and gynaecology.

Three centuries later, Soranus of Ephesus (98-138 BC), probably the most important gynaecologist of Graeco-Roman antiquity, described the female anatomy in the four books of his Gynaeciorum Commentarii (also extant in fragments only). His detailed instructions to midwives served as a textbook until relatively recently.

Passing references to women playing a role in ancient medicine, whether as midwives, doctors or authors, are also found in the epigrams of Martial (c. 38-104 AD) and the satires of Juvenal (late $1^{\text {st }} /$ early $2^{\text {nd }}$ century AD). So too, Pliny the Elder (23-79 AD) refers cryptically in his Natural History (H.N. hereafter) to a number of women who wrote treatises on aspects of obstetrics and gynaecology, often apparently for the training of midwives. For instance, Sotira, an obstetrix, gave advice on fever which can occur on the third and fourth days post partum as well as prescribing treatment for troublesome menstrual periods (XXVIII.23, 83). Salpe, who came from Lemnos and was an obstetrix 
as well as a poetess, wrote inter alia about female diseases (XXVIII.23, 82). ${ }^{20}$ Then there were Lais ${ }^{21}$ and Elephantis, both probably of the $1^{\text {st }}$ century AD. The latter was possibly also the author of obscene poetry highly admired by the emperor Tiberius. ${ }^{22}$ These two women both taught in Rome and both wrote on menstrual problems, but they differed radically in their view of aspects such as the agents which bring about abortion or can induce fertility or infertility. Pliny (H.N. XXVIII.23.81) thus advocates giving neither author credence. There was also Olympias of Thebes (fl. c. 25 AD), who wrote on the induction of abortions, menstrual problems, infertility, the prevention of miscarriages and female diseases in general (Pliny, H.N. XX.84.226).

One of the most influential physicians and prolific writers of the Latin Occident, Galen (AD 129-c.200) also made an important contribution to gynaecology and commented appreciatively on the role of midwives. Two later medical writers from North Africa who probably drew on his gynaecological work were Vindicianus, in his Gynaecia (late $4^{\text {th }}$ century AD), and Caelius Aurelianus, in a work of the same name ( $5^{\text {th }}$ century AD).

In the $4^{\text {th }}$ century $\mathrm{AD}$ the Christian writer Decimus Ausonius wrote with great admiration of his aunt Aemilia Hilaria, a woman vowed to virginity, "who was just as experienced in medical matters as any man". ${ }^{23}$

In a four-part encyclopaedia, the Tetrabiblion, written in the $6^{\text {th }}$ century AD by Aëtius of Amida in Mesopotamia, we find information about the female doctor Aspasia, who lived in Rome in the $2^{\text {nd }}$ century

20 She is also said to have provided genuine recipes for remedies for earache, toothache, sore eyes and even malaria, using the most off-putting ingredients (HurdMead 1938:57), but this can not be verified in the primary sources.

21 Hurd-Mead (1938:41) writes of Lais that her speciality was to treat malaria with menstrual blood, and she or another contemporary is said to have reported a cure for epilepsy by an attack of malaria ...

This cannot be verified in the primary sources.

22 Suetonius, Tiberius 43. Martial (12.43.4) also refers to Elephantis as a writer of obscene poetry, and Galen (K XII.416) is familiar with her as the author of pseudo-medicinal tracts on cosmetic remedies.

23 Ausonius, Parentalia 6. 
$\mathrm{AD}$ and wrote on problems in obstetrics and gynaecology. She is praised for her skill in the diagnosis of foetal positions and for her treatment of menstrual problems. She appears to have taken pains to communicate to her pregnant patients all the risks of abortion associated with certain activities. ${ }^{24}$

The earliest and only surviving text written by a female doctor is that of Metrodora ( $2^{\text {nd }} / 3^{\text {rd }}$ century AD). It is titled On the suffering of mothers as women, and it discusses, inter alia, diseases affecting the uterus, abdomen and kidneys as well as agents to counteract sterility, while also providing three recipes for contraception. ${ }^{25}$ She appears to have been extremely learned and her medications to have been completely original.

For the sake of completeness, we must also mention certain works which are only partly extant, namely those of Theodorus Priscianus (fl. c. $400 \mathrm{AD}$ ), the personal physician of the Emperor Gratian, who wrote a work on the medical problems of women. In addition, two books of questions and answers on obstetrics - a sort of catechism for midwives - were written in the $6^{\text {th }}$ century AD by an author called Muscio or Moschion. These were discovered as late as the $16^{\text {th }}$ century, and later found to be based mainly on Soranus's Gynaeciorum Commentarii.

\subsection{Epigraphic sources}

Valuable information on the professions and careers of women in ancient medicine is also provided by epigraphic material. In contrast to the literary sources, in which the experiential world of women is usually represented from a male perspective ${ }^{26}$ which cannot be taken as his-

24 Cf. Hurd-Mead (1938:64-66) for a detailed discussion of Aspasia's contribution to the Tetrabiblion; it apparently covered a wide area and she was "... a highly intelligent surgeon and obstetrician, indeed, quite the equal of any man of her time."

25 A summary of this text may be found in the Society for Ancient Medicine Review 19 (1991):179-81.

26 Cf. Beard (1993:33):

$[A]$ ncient literature is not evidence for women's lives in antiquity; it is a series of representations of women by men, and we cannot hope to understand what it is saying, unless we reflect on who is speaking, to whom, in what context and why ... 
torically accurate, funerary inscriptions and commemorative inscriptions offer direct, objective evidence about the person concerned. Unfortunately many Greek and Roman grave inscriptions reveal little more than a name, which makes it impossible to situate these women in a specific time and context. A few significant ones will now be briefly discussed as exemplifying the role played by women in the field of medicine from the earliest times.

Phanostrate, from Acharnai in Attica, was the wife of a Milesian citizen. According to her Greek inscription (c. 350 BC) she was both a midwife (maia) and a doctor (iatros):

Phanostrate, a midwife and physician, lies here. She caused nobody any pain, and all mourned her death. ${ }^{27}$

The relief accompanying the inscription represents Phanostrate as a midwife, surrounded by children. The combination of the two professions, and the fact that the Greek word for doctor is given in the masculine, iatros, makes it very clear that this is not a reference to a "wise woman" of a small village, but to someone who offered a much more extensive service than a mere midwife and, on the grounds of her knowledge and achievements, could justifiably lay claim to the term doctor.

Among inscriptions from Roman times we have that of the aged Claudia Trophima, who may well have practised right up to her death at 75 .

To Claudia Trophima, midwife. Titus Cassius Trophimus, her son, to his most gentle mother, and Tiberius Cassius Trophimianus to his grandmother, and to their descendants. She lived 75 years and 5 months. ${ }^{28}$

Others are known to have begun practising their profession very early, such as the Roman Poblicia Aphe, an emancipated slave who was already a practising midwife when she died at 21 .

Poblicia Aphe, midwife, freedwoman of Gaia. May your bones rest peacefully. She lived 21 years. $^{29}$

27 Pleket (1969: no. 1); Pomeroy (1978:499-500); Lefkowitz \& Fant (1992: no. 376).

28 Corpus Inscriptionum Latinarum 9720.

29 Ibid. 9723. The name "Gaia" (abbreviated C.) may refer to any woman, irrespective of her actual name: "C. 1(iberta)" may thus be translated as "liberated by a woman" (i.e. somebody's freed slave). 
Then there is a famous terracotta relief of a medical couple from Ostia ( $2^{\text {nd }}$ century AD): it shows Scribonia Attike assisting a woman sitting on a birth-stool in her confinement ${ }^{30}$ while her surgeon husband, M. Ulpius Amerinus, tends to a patient's leg on the adjacent relief.

In a commemorative inscription from the $1^{\text {st }}$ century $\mathrm{BC}$ we read that the city of Tlos in Lydia in Asia Minor gave official permission to Antiochis, the daughter of Diodotos, to erect a statue of herself on the grounds of her experience in medicine. ${ }^{31}$ This woman working in Rome must indeed have enjoyed great respect in her home town. Galen, too, refers to her as the originator of medicine for pain in the spleen, as well as for gout in the hip and for rheumatism. ${ }^{32}$ The famous doctor Herakleides of Tarentum ( $1^{\text {st }}$ century AD) also dedicated a book on nasal bleeding to her. She was thus a respected practitioner in her own right, and on an equal footing with her male colleagues.

An interesting proof of family connections in the medical profession is provided by a moving funerary inscription from Pergamum ( $2^{\text {nd }}$ century AD), composed for the female doctor Pantheia by her husband Glykon, himself a doctor and the son of a doctor, Philadelphus, who had been buried in the same sepulchre:

\footnotetext{
Receive, Pantheia, my wife, the farewell greeting of your spouse, who is cast into eternal mourning by the fate which caused your death. Because never before did Hera, patroness of marriage, see a spouse with such perfection of beauty, temperament and wisdom as you. You gave me sons, the images of myself. You watched in turn over your husband and children. You managed the household capably, and along with me you enjoyed fame as a medical practitioner because, dear wife, you were no less qualified than $I$ in the art. Therefore Glykon, your husband, has buried you in this sepulchre, in which the body of the deceased Philadelphus also lies buried, and in which I myself will rest after my death; as I shared your marriage bed, so shall I lie beside you underground. ${ }^{33}$
}

30 Discussed in Krug (1993:196).

31 Discussed in Pleket (1969: no. 12); cf. also Lefkowitz \& Fant (1992: no. 369).

32 Cf. Realencyclopaedie der klassischen Altertumswissenschaft Band VIII, Suppl. 14 (1974) 48-49 s.v. Antiochis no. 8, and Krug (1993:97).

33 Pleket (1969:32-33, no. 20). Another inscription relating to a medical married couple is that of Obrimus and his wife, Ammina, from Cilicia Trachea in Asia Minor $\left(2^{\text {nd }} / 3^{\text {rd }}\right.$ century AD), Pleket (1969:39 no. 27$)$. 
In an inscription from Neoclaudiopolis in Asia Minor $\left(2^{\text {nd }} / 3^{\text {rd }}\right.$ century $\mathrm{AD}$ ), a spouse finds another way to word his pain at the departure of his wife Domnina, a doctor:

You hastened to the immortal gods, Domnina, and have forgotten me, your husband. You elevated your body to the starry heavens. People will say that you did not die, but that the gods snatched you up because you saved your country from disease. Farewell; may you find joy in the Elysian fields, though you have left only suffering and everlasting pain for your loved ones. ${ }^{34}$

Domnina may well have died during the Antonine Plague, which struck the whole Roman Empire in the latter part of the $2^{\text {nd }}$ century AD. ${ }^{35}$

From Merida in Spain we have a funerary inscription for Iulia Saturnina, composed by her husband Cassius Philippus to "an incomparable spouse, the best medica, a very virtuous woman". On the reverse of the stone bearing the inscription there is a relief of a baby wrapped in a blanket. ${ }^{36}$

Other funerary inscriptions for female doctors (or references to them in such inscriptions) include those of Asyllia Polia from Carthage ( $1^{\text {st }}$ century AD),${ }^{37}$ Primilla $\left(1^{\text {st }} / 2^{\text {nd }}\right.$ century AD $),{ }^{38}$ Terentia Prima $\left(1^{\text {st }} / 2^{\text {nd }}\right.$

34 Pleket (1969:38 no. 26). Cf. also Lefkowitz \& Fant (1992: no. 374).

35 See Retief \& Cilliers (2000:268) for further information in this regard.

36 CIL II.497. Reference taken from Jackson (1988:86) and Gardner (1986:240).

37 Reference in Gardner (1986:240); according to Hurd-Mead (1938:89), the tablet containing this inscription comes from a Christian necropolis, and is

a small but very beautifully inscribed tablet to a woman doctor, Asyllia.

The slab is of dark green stone, about $30 \times 25 \mathrm{~cm}$, and reads: "Here lies

Asyllia Polia, daughter of Asyllus, woman doctor; she lived sixty-five years.

Fuscius, her freedman, made [this tomb] at his own expense."

It is doubtful, however, whether its provenance could have been a Christian cemetery if it dates from the $1^{\text {st }}$ century; a cemetery for prominent officials is more likely.

38 To my sacred goddess. To Primilla, a doctor, daughter of Lucius Vibius Melito. She lived 44 years, 30 of them with Lucius Cocceius Aphthorus, without causing any strife. Aphthorus built this monument for his best, chaste wife and for himself (Corpus Inscriptionum Latinarum VI.7581, reference taken from Lefkowitz \& Fant 1992: no. 370). 
century $\mathrm{AD})^{39}$ and Victoria, to whom the emperor Gratian's personal physician, Theodorus Priscianus, dedicated his book on gynaecology in the late $4^{\text {th }}$ century $\mathrm{AD}$, with the words: artis meae dulce ministerium ("the dear mistress of my art"). ${ }^{40}$ Then there was Mousa, whose grave bears a relief depicting her with a book-roll in her hand as an indication of her learning. ${ }^{41}$

\section{PROFESSIONAL TRAINING}

\subsection{Midwives}

Midwives, i.e. women who regularly assisted at births, initially received little more than a rudimentary practical training from other midwives (Drabkin 1944:349). There was probably a family tradition, i.e. mothers training their daughters (French 1987:72) and female slaves may have undergone some sort of apprenticeship with their mistress or an experienced midwife. This "in-service training", which probably began at an early age, was supplemented from the Hellenist period onwards ( $4^{\text {th }} / 3^{\text {rd }}$ century BC) by study material on obstetrics and gynaecology. ${ }^{42}$ Texts included Herophilus's Maieutikon, an influential practical textbook for midwives, followed by Soranus's handbook for midwives and Galen's work on the anatomy of the womb (dedicated to a midwife, which indicates that she was literate). The last-mentioned works were later translated from Greek into Latin, and remained standard texts for midwives until long after the Middle Ages.

39 To Terentia Nice, freed by Terentia Prima the doctor. Mussius Antiochus and Mussia Dionysia, her children, erected this for their mother, who deserved it (Corpus Inscriptionum Latinarum VI.9619, reference taken from Lefkowitz \& Fant 1992: no. 371).

40 Reference taken from Jackson (1988:86).

41 Cf. Krug (1993:196), which also contains a picture of this grave relief (illustration 87 on p. 196).

42 Pliny refers in H.N. XXVIII.81-84 to the now lost works of Salpe and Lais on obstetrics; these works, however, are likely to have contained a significant proportion of superstition. 
The healing hand

\subsection{Female doctors}

Little is known of the training of female doctors. Although certain centres, such as Cos, Cnidos, Alexandria, and later Rome and Pergamum, were very active in medical research, it is unlikely that women could have undergone any training there. There is an interesting anecdote from the fables of Hyginus which, if accepted at face value, would imply that, under certain favourable circumstances, women could receive training from scientifically trained doctors - but it is of doubtful authenticity. It relates that early in Greek history, before there were midwives in Athens, women often died during childbirth because they were too modest to discuss their problems with male doctors. ${ }^{43} \mathrm{~A}$ young Greek woman, Agnodike, therefore disguised herself as a man and served a medical apprenticeship under a certain Herophilus. She became so popular among her female patients that she was charged by her male colleagues of having seduced them. In court, she revealed her sex and was acquitted. The Athenians then altered the law which had barred women from becoming doctors, and from then onwards freeborn women were permitted to study medicine.

In the course of time, the story was elaborated and quoted on many occasions in the history of medicine ${ }^{44}$ as well as being cited as a precedent for a wide variety of actions by campaigners for women's rights, ${ }^{45}$ especially from the $17^{\text {th }}$ century onwards, when midwives and female doctors had to defend themselves within the male-dominated medical profession. It later came to be seen as a historical occurrence, ${ }^{46}$ but the majority of modern scholars doubt its authenticity. ${ }^{47}$ The most we can

43 Cf. inter alia Euripides's Hippolytus 293-296 in which the wet-nurse consoles Phaedra, telling her that if her problem is an "unmentionable disease" there are women present who can assist her, but if it may be spoken of to men, doctors should be called.

44 Cf. King (1986:69 n. 6) for examples of the many occasions on which this story has been quoted over the centuries by writers on a wide variety of subjects.

45 "Agnodike has been many things to many writers with a particular position to defend" (King 1986:58). Some saw her as a pioneer, others as an opponent of caesarean section or of abortion.

46 See inter alia Pomeroy (1978:500) and Fantham et al. (1994:168).

47 Von Staden (1989:38-40) views the story with scepticism, among other things because in Hyginus's book it belongs to the genre of "fable" and appears under 
probably infer from it is that women were indeed initially excluded from the medical profession in ancient Greece, possibly more by custom than by legislation (Fantham et al. 1994:68), but that it later became more usual for them to enter it.

What do we know about the training of female doctors? We can deduce that, like that of their male counterparts, it had a mainly practical focus, as well as involving a form of apprenticeship to other doctors. In some cases the medical profession seems to have become a family tradition, as appears to have been the case with Antiochis (mentioned above), who would have received her first encouragement and training from her father, himself a famous doctor. There were also medical married couples, like Pantheia (also the daughter of a doctor), whose husband composed the incomparable grave inscription quoted above. Apart from the training which such women would have received from a father or a spouse, they could also have used the books written for midwives, as cited above. In this connection, we have seen that the grave relief of the female doctor Mousa, a iatrinê of the $2^{\text {nd }} / 1^{\text {st }}$ century $\mathrm{BC}$, depicts her with a book-roll in her hand as a sign of her learning.

In general, it may be said that the training of female doctors, like that of their male peers, was focused on practice rather than on a strict theoretical foundation, and that medical skills would most often be transmitted from father to daughter or from husband to wife, or by means of apprenticeship, rather than by means of enrolment at a medical school or in a sect or cult. ${ }^{48}$ However, it must be borne in mind that medical training did differ widely from period to period, place to place, and person to person. ${ }^{49}$

the heading "mythical inventors" after the contributions on Cheiron the Centaur and Apollo and his son Aesculapius. He does, however, believe the story to have a historical substratum (1989:80): Herophilus's Maieutikon could possibly have given rise to it. King (1986:54) also casts doubt on the authenticity of the story and points out that the fact that Herophilus, to whom Agnodike is anchored, was a historical figure, does not prove Agnodike's historicity. King analyses the story as pure myth, seeing the revelation (anasyrmos) as its central idea - the motive of a disguise assumed in order to enter a forbidden (here, male) territory, followed by a revelation, also appears in several other myths.

48 Drabkin (1944:334 and 351); Scarborough (1969:125-128).

49 Cf. the detailed article by Kudlien (1970) 


\section{PERSONAL CHARACTERISTICS AND QUALIFICATIONS}

\subsection{Midwives}

In his Gynecology (I.4-5) Soranus of Ephesus provides us with a unique description of the essential characteristics and skills of a midwife. He asks first:

What is a midwife? A woman learned in all the causes of female diseases, and also skilled in general medical practice.

He then provides an outline of the personal characteristics and qualifications of the ideal midwife which was to remain the norm for many centuries. Certain aspects will be highlighted here.

According to Soranus, a midwife must be able to read and write, ${ }^{50}$ she must have a thorough knowledge of the theory and practice of obstetrics; she must enjoy her work, or else she will not be able to persevere in her demanding task; she must always be sober and lead an honourable life, since women confide their heart's secrets in her; she must not be superstitious or given to panic; she need not necessarily have borne children, because not only they show sympathy with women in labour; she must not be too talkative $;{ }^{51}$ nor must she be avaricious, which might make her susceptible to bribery by women wanting illegal abortions; she must be physically strong and healthy, with long, slim fingers and soft hands (which would mean that she should not work with wool, traditionally a female task).

50 This was not automatically the case - the literacy level in Hellenistic Greece is estimated to have been about $20-30 \%$ during the 4 th/3rd centuries BC. In Rome it was slightly higher in the early Empire, as it was in Roman Egypt where the entire administration depended on written documentation. Among women and slaves the level was even lower, but it is very difficult to generalise because there were various degrees of literacy and great differences between various times and places. For a detailed discussion, cf. Harris (1989).

51 This is confirmed by Pliny (H.N. 28.7.38), who writes admiringly of the inherent nobility and the unobtrusive, quiet way of life of several midwives. 


\subsection{Female doctors}

We have no similar description of the characteristics and skills essential to a female doctor, but since the two professions overlapped to such a great extent, we may assume that the profile of the ideal female doctor would be in line with that given by Soranus of the ideal midwife.

\section{THE TASK}

\subsection{Midwives}

As noted above, one of the earliest descriptions of the task of the midwife is to be found in Plato's dialogue Theaetetus 149, where he analyses the role of the midwife from a philosophical perspective and uses it as a basis of comparison for Socrates's explanation of his role as a teacher of the youth. This dialogue states that the task of the midwife is to initiate the birth process by means of medicaments and incantations; to ease difficult labour, and (where necessary) to bring about miscarriages. The association made here by a serious philosopher such as Plato between the birth process and the magical or mysterious is a reflection of the feelings of the average early Greek in respect of this borderarea of life, which was traditionally imbued with religious and magical practices and was regarded as exclusively the province of women. 


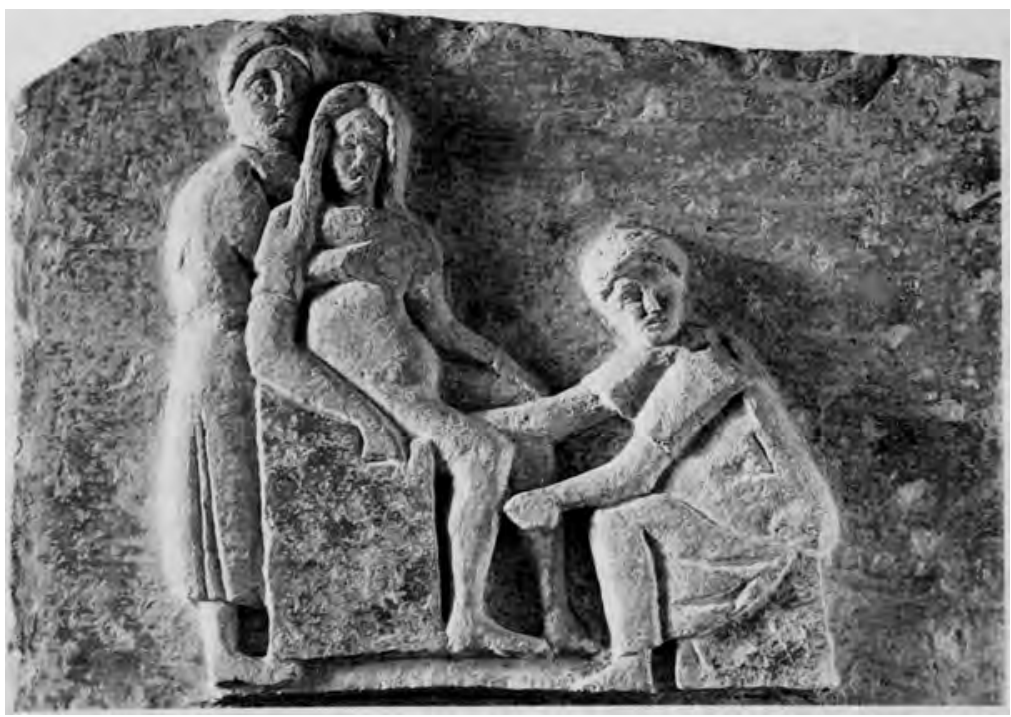

Figure 27: A midwife performing a delivery whilst her colleague holds the patient who is seated on an "obstetrical chair", grasping the special handles provided.

A more precise description of the task is found some centuries later in Soranus of Ephesus's Gynecology, which tells us that the midwife has to assist at the confinement, ${ }^{52}$ examine the baby, announce its sex, and inform the mother as to whether it is well-formed and worth raising. Soranus also gives instructions on how she must cut the umbilical cord, remove the afterbirth if it does not detach itself, and care for the baby. In line with her tasks, she is called maia or maieutria (midwife), or omphalotomos (the one who cuts the umbilical cord) or akestris (the healing woman). Her task thus appears to have involved much more than mere assistance at confinements. Indeed, Soranus (Gyn. III.3) notes that midwives were also called in rather than male doctors in cases of diseases specific to women and that, since women doctors were

52 Male doctors were indeed summoned to difficult confinements, but would only give the necessary instructions, to be executed by the midwives (Galen, Natural Faculties K III.3.151). 
always fewer in number than their male colleagues, midwives were consulted about a wide range of female diseases.

\subsection{Female doctors}

Female doctors also had a great deal to do with female diseases and births, and therefore were consulted mainly by female patients. It has already been shown that women preferred female doctors. ${ }^{53}$ There are, however, also many references to female doctors treating far more than just gynaecological problems - the inscriptions of Antiochis, Pantheia, and Domnina, discussed above, all indicate that their activities covered a far wider field than female diseases.

\section{STATUS}

\subsection{Midwives}

It goes without saying that there was great variation in the skills and status of midwives. Soranus refers to three "degrees" of midwife (Gyn I.3-4):

(i) Those who were technically very skilled, such as the "wise women" of the village communities, who did their work without fuss and helped bring many children into the world - as exemplified by the grave inscription of Julia Pieris of Trier:

Iulia Pieris, midwife. Here she lies. She was in her life a burden to nobody (Jackson 1988:97).

(ii) A second, more advanced group, also learned in the theoretical aspects of gynaecology and obstetrics.

(iii) A third group whose members were actually the equal of doctors and who had been trained in all types of treatment (medicaments, dietetics and even surgical interventions) before devoting themselves to the profession of midwifery.

There appears to have been some difference between the status accorded to midwives in the mainly Greek-speaking Eastern Mediterranean and in the Roman Occident (French 1987:72). In the East,

53 Cf. above the anecdote about Agnodike (p. 178), and Jackson (1988:191 n. 11). 
specialised training commenced at an early date; the obstetric profession was more highly regarded; its practitioners enjoyed high status, and there was a good living in it. In the Roman Occident the situation was very different - among the thousands of grave inscriptions in the Corpus Inscriptionum Latinarum only sixteen are for women who can be identified as midwives. ${ }^{54}$ Of these, only one died a slave; the others were emancipated, or the daughters of emancipated slaves. From these inscriptions it thus appears as if many midwives were slaves ${ }^{55}$ who continued in the profession even after they had attained their freedom. ${ }^{56}$ It thus seems as if free-born women did not practise midwifery in the Roman Occident. Furthermore, nine of the sixteen midwives identified came from the great aristocratic Roman families, or were clearly members of the emperor's court; thus large, wealthy households appear to have had their own midwives.

\subsection{Female doctors}

Female doctors do not appear to have been restricted to a single social class, but to have come from various strata of society; most were freeborn citizens, some even from the highest echelons, but in the Roman Occident we also find slaves and emancipated slaves, as in the case of midwives (Jackson 1988:86). Juvenal (Satire II.141) and Martial (Epigrams XI.60 \& XI.71) both refer to female doctors as coming from elevated circles, while further down the social scale grave inscriptions often refer to medicae.

Doctors (including women) enjoyed various privileges; Julius Caesar, for instance, gave citizenship to all doctors practising in Rome, ${ }^{57}$

54 CIL VI. 4458, 6325, 6647, 6832, 8192, 8207, 8947, 8948, 8949, 9720-5 \& 37810 (references taken from French [1987:82 n. 28]).

55 French (1987:72) demonstrates that the first names of the midwives in the funerary inscriptions confirm the hypothesis that they were of slave origin: eight of them have Greek names (and may thus have been highly-trained slaves bought by wealthy Roman families in the East) while the Latinised names of the others (Veneria, Hilaria, Imerita) are also typical slave names.

56 E.g. CIL VI. 6325, 8947, 9721 \& 9723 (references taken from Jackson [1988: 192 n. 53]).

57 Suetonius, Divus Julius 42. 
while later emperors exempted them from taxation. The statue and inscription of Antiochis described above also exemplify the recognition given for outstanding medical services to the community.

\section{REMUNERATION}

Whatever the regional or socio-economic backgrounds of midwives or female doctors, their services did not come cheap: there are many legal provisions indicating that midwives, for example, enjoyed a status and remuneration comparable with that of their male colleagues. ${ }^{58}$ It also appears that slaves who practised the profession could earn enough money to buy their freedom.

\section{CONCLUSION}

In contrast with the uphill battle of women all over the world, particularly in the $19^{\text {th }}$ and early $20^{\text {th }}$ century, to gain access to medical schools, ${ }^{59}$ it seems from the foregoing survey that from the $5^{\text {th }}$ century $\mathrm{BC}$ onwards women in the ancient world were increasingly at liberty to practise medicine. Although the number of women in the profession was always smaller than that of their male colleagues possibly as a consequence of domestic duties - they enjoyed much the same opportunities and were accepted without prejudice by their respective communities. Most were midwives, but many practised as doctors and were even afforded special honours for their expertise. Some even committed their learning to writing, and were acknowledged in later, authoritative works.

58 For example, the Codex Iustinianum 6.43.3 determines the monetary value of slave medici and obstetrices bequeathed to beneficiaries to be equal (60 solidi). Cf. also French (1987:83 n. 36).

59 Cf. in this regard the book by Bonner (1992). 


\section{REFERENCES}

\section{BEARD M}

1993. The Classic woman. History Today 43:29-35.

\section{BENEDEK T G}

1975. The roles of medieval women in the healing arts. In: D. Radcliff-Umstead (ed.), The roles and images of women in the Middle Ages and Renaissance. Pittsburgh: University of Pittsburgh Press.

\section{BONNER T N}

1992. To the ends of the earth: women's search for education in Medicine. Cambridge MA: Harvard University Press.

\section{Cilliers L}

1993. Where were the doctors when the Roman Empire died? Geneeskunde 35 (7):10-23 [pp. 62-78 in this volume].

\section{ClaAssen J-M}

1998 Feminisme en die klassieke Oudheid. Acta Academica 30(1):32-64.

\section{DRABKIN I E}

1944. On medical education in Greece and Rome. Bulletin of the History of Medicine 15:333-351.

FANTHAM E et al. (EDS.)

1994. Women in the classical world. Image and text. New York \& Oxford: Oxford University Press.

\section{FRENCH V}

1987. Midwives and maternity care in the Greco-Roman world. In: M. Skinner (ed.), Rescuing Creusa: new methodological approaches to women in antiquity. Lubbock, Texas.

\section{GARDNER J E}

1986. Women in Roman law and society. London: Croom Helm.

\section{GREEN M}

1989. Women's medical practice and health care in Medieval Europe. Signs: Journal of Women in Culture and Society 14(2):434-473.

\section{GREILSAMMER M}

1991. The midwife, the priest, and the physician: the subjugation of midwives in the Low Countries at the end of the Middle Ages. Journal of Medieval and Renaissance Studies 22(2):285-329.

\section{HALPERIN D N M}

1990. Why is Diotima a woman? Platonic eros and the configuration of gender. In: D.M. Halperin et al. (eds.), Before sexuality: the construction of erotic experience in the ancient Greek world. Princeton: Princeton University Press. 


\section{HARRIS W V}

1989. Ancient literacy. Cambridge MA: Harvard University Press.

\section{HuRd-MEAd K C}

1938. A bistory of women in medicine from the earliest times to the beginning of the nineteenth century. Haddam Conn.: The Haddam Press.

\section{JACKSON R}

1988. Doctors and diseases in the Roman Republic. London: University of Oklahoma Press.

\section{JUVENAL}

1918. Satires (transl. G.G. Ramsay). Cambridge MA: Harvard University Press. Loeb Classical Library.

\section{KING H}

1986. Agnodike and the profession of medicine. Proceedings of the Cambridge Philological Society 32:53-75.

\section{KRUG A}

1993. Heilkunst und Heilkult: Medizin in der Antike. München: Verlag C.H. Beck.

\section{KUDLIEN F}

1970. Medical education in classical antiquity. In: C.D. O'Malley (ed.), The history of medical education. Berkeley: University of California Press, pp. 3-37.

\section{NUTTON V}

1985. Murders and miracles: lay attitudes towards medicine in classical antiquity. In: R. Porter (ed.), Patients and practitioners: lay perceptions of medicine in preindustrial society. Cambridge: Cambridge University Press.

\section{LEFKOWITZ M R \& FANT M B (EDs.)}

1992. Women's life in Greece and Rome: a source book in translation. Baltimore: The Johns Hopkins University Press.

MARTIAL

1993. Epigrams (transl. D.R. Shankleton-Bailey). Cambridge MA: Harvard University Press. Loeb Classical Library Vol. II.

\section{PAULY-WISSOWA-KROLL}

1974. Paulys Realencyclopädie der klassischen Altertumswissenschaft Band VIII, Suppl. 14. Stuttgart: Metzler.

\section{PLATO}

1935. The Republic, Books 6-10 (transl. P. Shorey). Cambridge MA: Harvard University Press. Loeb Classical Library Vol. VI.

1021. Theaetetus. Sophist (trans. H.N. Fowler). Cambridge MA: Harvard University Press. Loeb Classical Library Vol. VII. 


\section{Pomeroy S B}

1978. Plato and the female physician (Republic 454d2). American Journal of Pbilology 99:496-500.

\section{PleKet H W}

1969. Epigraphica. Vol. II. Texts on the social history of the Greek world. Leiden: E.J. Brill.

\section{PLINY}

1952. Historia Naturalis (transl. H. Rackham). Cambridge, MA: Harvard University Press. Loeb Classical Library Vol. IX.

\section{Retief F P \& Cilliers L}

2000. Epidemics of the Roman Empire, 27 BC-AD 476. South African Medical Journal 90(3):267-272.

\section{ROSHER W H}

1965. Ausführliches Lexikon der griechischen und römischen Mythologie Vol. II.2. Hildesheim: Olms (repr.).

\section{SCARBOROUGH J}

1969. Roman medicine. London: Thames \& Hudson.

\section{SUETONIUS}

1998. Lives of the Caesars (transl. J.C. Rolfe). Cambridge MA: Harvard University Press. Loeb Classical Library Vol. I.

\section{SKINNER M}

1987. Rescuing Creusa: new methodological approaches to women in antiquity. Lubbock, Texas: Texas Tech. University Press.

\section{VON STADEN H}

1989. Herophilus: the art of medicine in Early Alexandria. Cambridge: Cambridge University Press.

\section{WASSERMANN H P}

1997. Geneeskunde in die Bybel. Pretoria: J.L. Van Schaik. 